\title{
Skirmishes in Aboriginal history
}

\author{
Peggy Brock
}

In late 2002 Keith Windschuttle published The fabrication of Aboriginal history, and suddenly the subject of the writing and researching of Aboriginal history was being discussed daily in the press, on the radio and television. ${ }^{1}$ The book was widely reviewed, opinion pieces were written about it, and seminars and public debates organised to discuss its controversial claims. ${ }^{2}$ Windschuttle set out to write a revisionist history of early encounters between Aboriginal people and colonists in Van Diemen's Land in which he questioned the level of violence and mortality of Aboriginal people in the early contact period. Windschuttle also attacked the historians whose research he challenged, accusing them of fabricating evidence to support their interpretations of the past. I will not venture along this embattled path, often referred to as 'the history wars'. Windschuttle's views are set out in detail in his book and on his web page. ${ }^{3}$ Two recently published books, The history wars (taking up the military metaphor) and Whitewash: on Keith Windschuttle's fabrication of Aboriginal history, put an alternative view and present a critique of Windschuttle's work. ${ }^{4}$ As much of this commentary points out, the debate about 'Aboriginal history' is not so much about the Aboriginal past as about an Australian national history. Windschuttle is quite explicit on this point: '[T]he debate over Aboriginal history goes far beyond its ostensible subject: it is about the character of the nation and, ultimately, the calibre of civilisation Britain brought to these shores in $1788^{\prime} .^{5}$ Macintyre argues that this controversy is just the latest in a series of debates surrounding Australian history and historians as the interpreters of Australian identity. Krygier and van Krieken in Whitewash also focus on the political aspects of Windschuttle's position throwing his accusations against 'revisionist' historians' lack of objectivity back at him. Marilyn Lake, in the same volume, suggests that rather than taking racial and national identities in colonial history as given, we should be striving for an approach in which the identities of coloniser and colonised are analysed as evolving through their mutual encounter. ${ }^{6}$

\footnotetext{
1. Windschuttle 2002a.
}

2. See the Australian Council of Professional Historians Association's website for historian Cathie Clement's commentaries on these debates, http:/ /www.historians.org.au/discus /

3. http://www.sydneyline.com/

4. Macintyre and Clark 2003; Manne 2003.

5. Windschuttle 2002b: 9.

6. Krygier and van Krieken 2003: 81-108; Lake 2003: 160-73. 
Revisiting the subject of 'Aboriginal history' now the media frenzy has died down (although not disappeared), it is clear that the Windschuttle-generated debate, while broad in its implications - the Australian national character and identity as it is reflected in the past - is only narrowly focused on certain aspects of Aboriginal history. Through his attack on the integrity of historians researching Aboriginal/nonAboriginal relations, Windschuttle has forced these historians onto the defensive, and in the public eye the argument becomes an esoteric one about footnotes and body counts on the frontier. ${ }^{7}$ The adversarial nature of the controversy makes it difficult for substantial issues, such as the nature of genocide and whether it applies to the Australian situation, or the nature of early encounters between Indigenous peoples and colonists, to be debated at other than a superficial level. ${ }^{8}$

While Windschuttle has succeeded in drawing public battle lines over certain aspects of historiography, ongoing skirmishes over the contested nature of the researching and writing of Aboriginal history continue. It is noteworthy that during the recent highly charged controversy, few Aboriginal voices were heard in the media, although some Indigenous historians have critiqued Windschuttle's book and the debate it initiated in review articles. Vicki Grieves noted that despite Windschuttle's attack on Tasmanian (and by implication all) Aboriginal people, they were sidelined, rather than central, to the debate:

To be caught in Australian political crossfire is symptomatic of the position of Indigenous Australians in Australian society over the past four decades at least. While the perception is that we are willing captives of the left, then we are often the targets of warriors of the right, such as Windschuttle. His argument with us may, or may not, be incidental (is the jury still out on this one?). It is extremely damaging generally, as it reiterates the colonialist, racist attitudes we have been chipping away at for some time. ${ }^{9}$

Another Indigenous historian, John Maynard, noted 'Historically, the Aboriginal political voice was silenced and in the contemporary setting it continues to be. This point is exemplified in the largely white "history wars" debate. ${ }^{10}$ Jill Milroy, a PalkyuNamal woman and Head of the School of Indigenous Studies at the University of Western Australia, claimed at a symposium in Perth to mark the launch of Whitewash that this debate was of no interest or relevance to Aboriginal people. She went on to say that with no formal qualifications in history she had been excluded from the profession, and was therefore free to be an Aboriginal historian in an Aboriginal way. Although these charges were not debated that evening, they reflect a long-lived discussion about the researching and writing of the Aboriginal past. It is this and associated issues of methodology and authorship which I want to revisit here.

'Aboriginal history' means different things in different contexts. To Windschuttle, Aboriginal history is about the interactions between British colonisers and the

7. Some examples of this public debate are HA Willis 28 December 2002: 16; Roger Sandall 23 December 2002: 11; Reynolds 14-15 December 2002: 11; Moses 13 January 2003: 9 . Lyndall Ryan's responses to Windschuttle's attacks on her scholarship are an example of the defensive responses the debate has generated. See Ryan 2002, 2003.

8. Bain Attwood attempted to bring this discussion into the public debate 6 January 2003: 13 .

9. Grieves 2003.

10. Maynard 2003: 139. 
Aboriginal people they encountered. He rejects the possibility that the Tasmanian Aboriginal people had a history before European interventions. He claims they had no social organisation or territorial base and were so depraved that their survival was accidental. ${ }^{11}$ Many other historians, while not condemning Aboriginal people to be a 'people without history',' 12 also research the interactions of Aboriginal and nonAboriginal people and refer to their field of study as Aboriginal history. Bain Attwood has suggested that this creates a paradox in which university-trained historians write about a past in which Aboriginal people are active participants, but the historians are inevitably constrained by their own intellectual and cultural values. While they may present a view of the past which takes account of Aboriginal perspectives and values, they will inevitably be different from their own:

Academic historians are barely familiar with the phenomenology, epistemology and ontology of the indigenous peoples of Australia whose behaviour we seek to interpret; instead, we tend to force Aborigines into our culture's paradigms of reason and logic, and equate them with ourselves in psychological terms so rendering them intelligible in our terms. ${ }^{13}$

Attwood is grappling with issues raised by the Annales School historians in their development of mentalite - historians' ability to understand the intellectual and cultural underpinnings of distant societies, whether that distance is temporal or cultural. Attwood goes on to argue that academic historians apply Eurocentric concepts to the Aboriginal past and suggests, following poststructuralist analyses, that history is a European concept, so the whole project is an extension of the colonial past we seek to represent. Attwood's article was published in the same year as Windschuttle's book The killing of history, in which he criticised such post-structuralist approaches to history and argued for an empirical methodology which he then pursued in The fabrication of Aboriginal history. ${ }^{14}$

Other Australian historians have tackled the contradictions inherent in interpreting the Aboriginal experience of colonial and neo- (or post-) colonial Australia using a range of paradigms. Before the recognition of Aboriginal history as a field of research, several historians in the mid-twentieth century, including Hasluck, Grenfell Price and Foxcroft, wrote about the policies which governed Aboriginal people's lives. ${ }^{15}$ Aboriginal people did not figure as active characters in these studies. These historians and the anthropologists (particularly AP Elkin) who influenced them, were strong advocates of assimilation policies in which people of mixed descent would become incorporated into mainstream society, as would their history. Hasluck and Grenfell Price noted that Aboriginal people had been subject to violence and appalling treatment in the past, although Hasluck was very careful about introducing such issues into his account: 'These cases have been cited, not for sensationalism, or to give undue prominence to the story of violence, but as a reflection of public opinion [of the time]. ${ }^{16}$ Three decades later the political scientist CD Rowley published Aboriginal policy and

11. Windschuttle 2002a: 103-13, 386.

12. Wolfe 1982.

13. Attwood 1994: 132.

14. Windschuttle 1994 .

15. Hasluck 1970 [1942]; Foxcroft 1941; Grenfell Price 1949.

16. Hasluck 1970 [1942]: 186. 
practice which, while concerned with policies and their implementation, was much more forthright than the earlier historians had been about the negative impacts of administrative practices and racial prejudice on Aboriginal people. ${ }^{17}$ Soon after this, Peter Biskup's Not slaves, not citizens considered government policies in Western Australia. Biskup made his viewpoint clear:

This book is not primarily about the aborigines of Western Australia. It is about the 'aboriginal problem' - the unending debate among white Western Australians, going back to the early days of settlement, about how the original inhabitants of the country should be subjugated, tamed, exploited, controlled, protected, preserved, bred out, uplifted or developed. In other words, the book will tell the reader, if he is an Australian of European origin, as much about himself and his society as it will tell him about aborigines. In a modest way the book is also a study in colonialism, using the term in its widest sense: Australia, like the Union of South Africa or the Union of Soviet Socialist Republics, 'contains its colonial problems within itself' ${ }^{18}$

By the early 1980s, historians were moving beyond an investigation of policies which impacted on Aboriginal people to a consideration of Aboriginal responses to policies and practices. For the first time Aboriginal people were presented as active participants in their own history. These historians tried to avoid Attwood's paradox. They made clear they were not speaking on behalf of Indigenous people, or writing from an Aboriginal perspective. Reynolds articulated this approach on the first page of his book:

The other side of the frontier examines the Aboriginal response to the invasion and settlement of Australia during the hundred years or so between the late eighteenth century and the early twentieth. It is a white man's interpretation, aimed primarily at white Australians in the hope that they will gain an appreciation of the Aboriginal part in the history of the continent during the last two hundred years. ${ }^{19}$

Reynolds' disclaimer does not necessarily exempt him from the implications of Attwood's paradox and Jill Milroy's claim against academic historians, or from the view that only Aboriginal people can research and write about the Aboriginal past because their lived experience and the understanding of that experience cannot be accessed by non-Aboriginal historians.

The notion that history can only be written by the subjects of that history derives from nationalist ideas that history is the teleological narrative of the nation or people and only they can articulate the essential essence of that historical experience. ${ }^{20}$ Many indigenous peoples have adopted this paradigm as a means of asserting their autonomy and separate identity within settler societies. Indigenous identity as national identity is reflected in the Canadian term 'First Nations', which establishes both the prior existence (as opposed to that of newcomers) of Native Canadians and their nationhood; and Aboriginal usage which refers to cultural or regional groupings as nations - the Koori nation or the Yorta Yorta nation. At the same time as Aboriginal

17. Rowley 1970a,b, 1971. See also Cowlishaw 1992: 26.

18. Biskup 1973: v.

19. Reynolds 1981: 1.

20. McBryde 1996: 9. 
people make claim to an identity as peoples (nations), some align themselves with the history of Indigenous peoples around the globe arguing that the history of First Nations in Canada or Maori in New Zealand/Aotearoa resonates closely with the Australian Aboriginal experience. They perceive themselves as sharing a common history of oppression as colonised people within nation states. ${ }^{21}$ These two forms of Indigenous identity - the national and international - look back to a pre-colonial past and forward to an international movement of Indigenous peoples, at the same time placing Aboriginal people outside Australian history. This suggests a different sort of paradox from that proposed by Attwood. In this paradoxical situation historians of Australian history may present Aboriginal people as an essential part of our national history, while nationalist Indigenous historians consider themselves separate from the nation state and its history.

From the late 1970s Aboriginal people began publishing their own accounts of the past, generally in the form of life histories - autobiographies and family or communal biographies. Some conform to the nationalist idea of Aboriginality, but most place themselves within the context of Australian history. Histories narrated by Aboriginal people tend to be centrally about kin and community, yet as a body of work they cover a wide range of experiences and knowledge. ${ }^{22}$ Indigenous authors come from a variety of backgrounds as is reflected in their writings. They include bureaucrats, politicians, activists, domestic workers and housewives, community leaders, 'stolen children', stock workers, artists and sportspeople. ${ }^{23}$ These writings are personal, as they come out of lived experience and oral accounts handed down from one generation to the next, rather than being based in archival research. While individual authors tend not to generalise from their own accounts, or use them as a basis for analysing the broader Aboriginal past, this growing literature does present a cross section of Indigenous knowledge and illustrates the impact of past policies and practices on the lives of individuals, families and communities. In presenting a wide panoply of Aboriginal experiences past and present, these accounts reflect the pervasive influence of nonAboriginal society which has insinuated itself into so many facets of Aboriginal existence. In these histories Aboriginal individuals, families and communities are encapsulated in a society which puts up barriers to their incorporation into mainstream society, while applying strong assimilative pressures on them. ${ }^{24}$ The method of research and the perspective of these authors is different from the approach taken by academic historians, but they present another side of the historical coin, not an entirely different historical currency. The context of government policies and legislation may not be emphasised as it is in many academic accounts, yet the impacts of colonial policies and racial attitudes are clearly reflected in the everyday lives of these people.

Indigenous academic historians are beginning to publish and enter the historiographical debates. The Centre for Australian Indigenous History has two Indigenous historians - Gordon Briscoe and Frances Peters-Little - on its staff, and

21. Dodson 1994.

22. See Attwood 1994 for a succinct overview of Aboriginal approaches to recalling and writing about the past; also Broome 1996.

23. Eg Lester 1993, Perkins 1975; Ward 1995; Tucker 1977; Nannup 1992; Bropho 1980, Rubuntja 2002.

24. Eg Langford, 1988; Pilkington, 1996; Roughsey 1984. 
the University of Newcastle has a number of Indigenous historians, including John Maynard and Vicki Grieves, who are undertaking research in Aboriginal history, ranging from regional histories to Aboriginal convicts, sports history, and the history of Indigenous health. ${ }^{25}$

The debates about Aboriginal history are not only about which past and whose past, but equally about how to research it. In 1969 Peter Corris aligned the emerging field of Aboriginal history in Australia with North American ethnohistory. ${ }^{26} \mathrm{He}$ points out that it is a methodology rather than the subject matter of research. Ten years later Isabel McBryde, an archaeologist, traced the origins of ethnohistory in North America and saw potential for its use in Australian based research. ${ }^{27}$ Ethnohistory developed out of a cross-disciplinary approach to the research of the past of societies which are/ were non-literate, or left few written records. The two main disciplines which inform ethnohistorical research are history and anthropology, although archaeology, geography, linguistics and related methodological approaches are also utilised. This cross-disciplinarity has been facilitated by changes in the disciplines themselves. The anthropologist Krech argues that 'Despite misgivings on both sides, anthropology and history have greatly influenced each other in recent years. The argument that all history is atheoretical, particularist, ideographic, and moralistic and that anthropology is theoretical, generalising, nomothetic, and value free is no longer tenable' ${ }^{28}$ Historian James Axtell made an early attempt to define the interdisciplinary field of ethnohistory by suggesting that ethnohistory is a 'form of cultural history or a sub-discipline of cultural anthropology' which produces 'scholarly offspring who bear the diachronic dimensions of history and the synchronic sensitivities of ethnology. ${ }^{29}$ Axtell also makes the important point that ethnohistory is a product of scholars' attempts to analyse the interactions of two societies and cultures, where each society is understood on its own terms, rather than the frontier-view in which the inevitable clash of cultures results in one society (the Indigenous) being doomed to extinction or irrelevance. ${ }^{30}$

Ethnohistorians investigating the history of societies that did not generate extensive written records have experimented with a range of sources to supplement these documents. Photographs, maps, archaeological data, linguists' and anthropologists' field notes are important sources. Oral accounts are frequently used, and are particularly important when researching societies where they have been the main means of communicating knowledge of the past. The process of collecting oral

25. Gordon Briscoe 2003; Maynard 1997, 2002. These and other Indigenous scholars are contributing book reviews of Aboriginal history to a range of journals, including Aboriginal History and Labour History. A recent issue of Studies in Western Australian History, is another strong indication that Indigenous historians are forging a place for themselves in documentbased, as well as oral-based historical research. Most of the articles were written by Indigenous postgraduate and undergraduate students Milroy, Host and Stannage 2001.

26. Corris 1969. In this article Corris states that, 'The simple fact is that there is as yet no history of an Aboriginal tribe, or of the Aborigines of any of the Australian states, or indeed any published historical study which keeps aborigines firmly in the foreground rather than the settlers, missionaries, or policy makers who had dealings with them' (1969: 202).

28. McBryde 1979.

Krech 1991: 350.

29. Axtell 1982: 5 .

30. Axtell 1982: 7. 
testimonies can have an important influence on the written history which develops from it as scholars encounter different historical discourses and ways of remembering the past. In Life lived like a story Julie Cruikshank recorded the life histories of three women of Athapascan and Tlingit ancestry in the Yukon Territory of Canada. Through this collaborative process her interests, 'shifted away from an oral history committed to documenting changes in social reality and toward an investigation of narrative forms for talking about, remembering and interpreting everyday life. ${ }^{\prime 31}$ Many Australian ethnohistorians, such as Peter Read, Deborah Bird Rose and Mary Ann Jebb have had similar experiences as they recorded and used life histories as primary texts in their research.

In North America, as in Australia, Indigenous peoples were first studied by anthropologists. Ethnohistory grew out of anthropology rather than history. ${ }^{32}$ Anthropologists dealing with American Indian land claims realised that they needed to access written sources used by historians and incorporate a temporal dimension into their research. About the same time historians began researching the past of indigenous and non-Western peoples. They found that anthropologists had gone before them, and as Axtell indicates, adopted some of their conceptual frameworks and methods. Ethnohistorians in the USA and Canada investigate the past of indigenous peoples of the Americas - not just in the United States and Canada, but in Central and South America as well. Thus ethnohistory describes a methodological approach, indicating the subjects of research without defining them in racial, ethnic or nationalist terms. ${ }^{33} \mathrm{It}$ does not prevent the ideological battles recently waged over 'Aboriginal history', but it might clarify issues for non-practitioners as well as practitioners by clearly separating the means of researching the past from its particular focus.

Corris was unsuccessful in his early attempt to have Australian historians adopt a similar approach to that taken in North America. Structural-functionalist anthropology predominated in Australia until quite recently. ${ }^{34}$ In the mid-twentieth century historians were influenced, not by anthropological concepts of culture, but by anthropologists' advocacy of assimilation for those people of mixed descent they considered de-culturated. AP Elkin worked tirelessly to have this policy implemented. He set out his theoretical premises in a 1951 article, 'Reaction and interaction: a foodgathering people and European settlement in Australia,'35 and advocated assimilation in many pamphlets and other writings. Historians, as we have seen, moved from investigations of policies regarding Aboriginal people, to a consideration of the impacts of policies on Aboriginal people. There was little integration with anthropological methodology or its conceptual frameworks.

Diane Barwick, an anthropologist from Canada, was perhaps the first to show Australian scholars how an ethnohistorical investigation could be undertaken, in her

31. Cruikshank 1990.

32. Sheridan 1988.

33. For examples of Canadian ethnohistory see Harkin 1997, Furniss 1995, Bruce Trigger 1985. Bruce Trigger has also written a critique of Elkins' approach, 1982.

34. Wolfe 1994; McBryde 1979.

35. Elkin (1951) makes an interesting comparison with the cultural anthropology of his American contemporaries such as Edward H Spicer who criticised Elkins' 'invariant sequences' (Spicer 1969: 541). 
research of Aboriginal communities in Victoria. ${ }^{36}$ Her focus on urban and agricultural Aboriginal people was an important development in Australian anthropology with its preoccupation with 'tribal' people whose Aboriginal culture was considered still to be intact. The historian Henry Reynolds' work was an early example of historical research influenced by anthropological concepts of Aboriginal kinship, social organisation, gender roles and warfare in his interpretation of those sources. ${ }^{37}$ By the late $1980 \mathrm{~s}$ both anthropologists and historians were reflecting ethnohistorical influences in their work. The historian Ann McGrath's study of Aboriginal labour in the pastoral industry of the Northern Territory and the east Kimberley epitomises this approach both in her research methods and her writing. ${ }^{38}$ She used a variety of source materials to supplement the written record, including many interviews which she collected while undertaking fieldwork among the communities she wrote about. Her book does not have a strong chronological narrative, but rather is organised thematically, influenced by anthropological cultural concepts. Mary Anne Jebb's recent book on the pastoral industry in the Kimberley adopts a similar approach. ${ }^{39}$ Jebb lived and worked with Kimberley communities over a number of years, collecting oral testimonies to produce a richly textured analysis of Aboriginal involvement in the industry.

On the other side of the disciplinary divide, anthropologists were turning to archival sources in their research. David Trigger's Whitefella coming and Diane AustinBroos' work on the Arrernte at Ntaria/Hermannsburg, are examples. ${ }^{40}$ Both these anthropologists studied Aboriginal people in mission environments. They undertook fieldwork, but put this in the context of the earlier mission days. Before the 1970s anthropologists had tended to view Christians as inauthentic and non-traditional Aborigines. In his published work CP Mountford, who undertook research at Ernabella Presbyterian Mission in Central Australia in 1949, ignored the mission environment and failed to mention that some of his Pitjantjatjara informants were Christians. ${ }^{41}$ Many anthropologists began historicising the context of their field-based research. Deborah Bird Rose's representation of interracial violence in the Victoria River region of the Northern Territory is a well known exemplar. ${ }^{42}$ Rose puts the accounts she collected within her own historical narrative structure to illustrate the cruelty and exploitation of life in the early pastoral industry.

The growing interest in oral history has encouraged historians, linguists and anthropologists to work closely with Aboriginal individuals and communities to assist them in bringing their accounts into the public domain. This assistance comes in many forms, but most commonly it involves interviews with Aboriginal historians, which are then transcribed and edited. Some of these histories are presented as first hand accounts by the Aboriginal author, others are integrated into an analytical or

36. Eg Barwick 1971. See also McBryde 1996: 1-15.

37. Reynolds 1981.

38. McGrath 1987.

39. Jebb 2002.

40. Trigger 1992; Austin-Broos 1994.

41. D Trudinger to GS McDonald, Superintendent of Technical Schools 29/8/1949, 5068 series 10 Ernabella Mission 1935-1965. National Library of Australia, Canberra.

42. Rose 1991. Peter Read (Read and Japaljarri 1978) and Jenny Green (Rubuntja and Green 2002) have used similar methods. 
interpretive framework established by the non-Aboriginal author. Bruce Shaw, Mary Anne Jebb, Stephen Muecke, and Bill Rosser have assisted in producing published firsthand accounts by Aboriginal people. ${ }^{43}$ Aboriginal authors such as Sally Morgan, Herb Wharton and Jackie Huggins have fulfilled similar functions by presenting accounts of close relatives or fellow workers. ${ }^{44}$ As previously mentioned some scholars have contextualised Aboriginal accounts within an historical narrative provided by the non-Aboriginal co-author. ${ }^{45}$ There are also more conventional Aboriginal autobiographies and biographies being produced where the intervention of an editor or co-author is not always explicit. ${ }^{46}$

The publication of these Aboriginal historical accounts has revolutionised the common understandings of the past by personalising trauma and oppression, as well as presenting Aboriginal humour and strength in the face of great difficulties. In ethnohistorical and methodological terms it also raises questions about authorship and Attwood's concern that 'we tend to force Aborigines into our culture's paradigms' ${ }^{47}$ Is the authentic Aboriginal voice lost in the publication processes of transcription, editing and interpretation? There was some early debate about the status of translation following the publication of Bruce Shaw's books in which he rendered Kimberley kriol into Aboriginal English. ${ }^{48}$ Since then transcribers and editors have grappled with methods that reproduce accounts verbatim, while making them accessible and intelligible on the written page. ${ }^{49}$ Similar issues have arisen in publishing Native American life histories. David Murray, in his book Forked tongues suggests:

Individuals in an oral culture have no context for the conception of autobiography which has been developed in literate cultures, and which depends on a set of interrelated common assumptions about the nature of self, its relation to history, its relationship of authorship to a text, and the concept of authenticity and authority which goes with this. The creation of an Indian autobiography has, therefore, required either the ability of a particular Indian to comply closely enough with standards of written English ... or, much more commonly, the collaboration of several people - the subject, a white editor or anthropologist, and often another Indian acting as translator. ${ }^{50}$

Another American scholar, Arnold Krupat, has categorised Native American writings to help identify the authorship of an 'autobiography':

Autobiographies by Indians' are individually composed texts written by the person whose life is described; 'Indian autobiographies' on the other hand, are not 'self-written', but are 'bi-cultural composite composition[s]' involving translators, editors and other interventions to produce the text. ${ }^{51}$

One way out of Attwood's paradox is to follow the lead of Murray and Krupat and make both Aboriginal and non-Aboriginal authorship and the process of research

\footnotetext{
43. Eg Shaw 1983; Munro with Jebb 1996; Roe with Muecke 1993; Rosser 1985, 1990.

44. Morgan 1989; Wharton 1994; Huggins 1994.

45. Rose 1991; Read and Japaljarri 1978; Rubuntja and Green 2002.

46. Eg Nannup 1992.

47. Attwood 1994: 133

48. Shaw 1984, 1985; McConvell 1985.

50. Murray 1991: 67.

51. Krupat 1985: 3.
} 
explicit. Informed readers can draw their own conclusions about provenance and authenticity of research.

Nevertheless, there are practical and serious problems of cross-cultural misunderstandings where Kriol or Aboriginal English are used. A recent example is Keith Windschuttle's mishearing of Peggy Patrick's account of a massacre in the Kimberley which her grandmother narrowly survived. ${ }^{52}$ Patrick's first language is Gija. Windschuttle understood her to be recounting her mother's account of a massacre which occurred in 1915 before she was born, rather than her grandmother's (rendered as 'mum mum' in her Kriol) memories of the massacre. He then claimed that as Patrick's mother was not alive in 1915, she had made up her account. ${ }^{53}$ This misunderstanding is no doubt largely due to Windschuttle's refusal to recognise the intercultural nature of Aboriginal history or to use ethnohistorical methods in his research, but it is also indicative of a general expectation among the public that historical accounts must be accessible and in a form of English they readily understand. This draws us to the question 'for whom is Aboriginal history written?'

Some Aboriginal writers use their histories to sustain an Aboriginal identity at the community level; ${ }^{54}$ others argue for an identity as a people; a few perceive their role as educators of the wider Australian society. ${ }^{55}$ Many Aboriginal intellectuals and politicians such as Noel Pearson, Marcia Langton, Mick Dodson, Aden Ridgeway, Patrick Dodson and Peter Yu are very conscious of how the past has influenced the present, but do not engage with the writing of history. ${ }^{56}$ Aboriginal Australia has not produced an historian who has played a similar role to the Native American historian, Vine Deloria Jr. who published Custer died for your sins in 1969. He gave an Indian account of American Indian history in which he not only criticised previous histories, but wrote an openly politicised interpretation of Indian experiences. He claimed:

Most books about Indians cover some abstract and esoteric topic of the last century. Contemporary books are predominantly by whites trying to solve the 'Indian problem.' Between the two extremes lives a dynamic people in a social structure of their own, asking only to be freed from cultural oppression. The future does not look bright for the attainment of such freedom because the white does not understand the Indian and the Indian does not wish to understand the white. $^{57}$

52. Patrick 2003; Clement 2003.

53. Clement 2003: 208.

54. Miller 1985: xvi1; Munro 1996: xv. See also Attwood's discussion, 1994: 128.

55. Huggins 1998: 1-2. She takes the view that although Aboriginal people are sick of the role of educators of the wider Australian community, they still maintain that role. See also Rosser 1990; Fesl 1993; Ginibi 1994.

56. Marcia Langton is an anthropologist and Professor of Australian Indigenous Studies at Melbourne University; Mick Dodson was one of the Commissioners and authors of the Bringing them home report and is now Professor of Indigenous Studies at ANU; Noel Pearson is a lawyer who was deeply involved in the negotiations with the Keating government over native title legislation; Patrick Dodson was Chair of the Reconciliation Council; Aden Ridgeway is a Democrat Senator in Federal Parliament; and Peter Yu was Chair of the Kimberley Land Council and involved in negotiations over native title legislation and other land rights issues.

57. Deloria 1969: 12-13. 
Deloria was activated by the radical politics of the 1960s and 1970s. That era produced poets and fiction writers such as Kevin Gilbert and Mudrooroo ${ }^{58}$ as well as songwriters and performers in Australia, rather than Indigenous historians. One reason Aboriginal historians have been slow to adopt historical or ethnohistorical approaches to research (other than their relatively recent access to higher education) is a deep suspicion of the written sources on which academic historians rely. James Miller, who used the archives to research his book Koori: a will to win, found the records Eurocentric:

However when the white men who held positive attitudes wrote about the Kooris whom they met, they interpreted events in their European way of thinking. When they wrote about injustices being committed against the Koori, they in fact wrote about injustices as Englishmen would understand the term. Rarely is the Koori point of view found in old documents. ${ }^{59}$

Henrietta Fourmile argued colonial control has continued through governmental control of the archives which has denied easy access to Aboriginal researchers. ${ }^{60}$ Jackie Huggins, one of a small handful of Aboriginal historians who engage with academic history, while concerned about the ethnocentrism of much Australian history has taken a more conciliatory approach. She echoes some of the concerns Deloria highlighted in 1969 in relation to the writing of American Indian history, yet she recognises that nonAboriginal historians can make a positive contribution to Aboriginal history and has worked cooperatively with some of them:

I think it is the responsibility of every historian, particularly if they are doing Australian history, to make some kind of commitment to the inclusion of Aboriginal people. Exclusion is a sorry story, but I would not want to be included if people didn't go about the process in a culturally appropriate way ... I think to say that writing about Aboriginal people is too hard is a great cop-out. If historians feel they have no position to speak from concerning Aboriginal people then just don't do it rather than stuff it up. ${ }^{61}$

Eve Fesl, an Aboriginal linguist, while deploring what she has termed the conspiracy of silence regarding the Aboriginal past, decided to correct the biases of the written record by analysing the way language has been used to misrepresent and justify white supremacy over Kooris. She deconstructs terms such as 'protection', 'assimilation' and 'reconciliation' to show the reality behind these benign words. ${ }^{62}$ Most of these Indigenous researchers in Australia have tended to challenge historians from outside the profession to ensure that historical research does not continue the colonial legacy. They write consciously for an Aboriginal readership with a hope that non-Aboriginal people will read and understand them.

The early non-Aboriginal scholars of Aboriginal history, as we have seen, wrote to inform non-Indigenous Australians. They wanted to introduce them to a view of Australia which had been hidden from them for much of the twentieth century. They were always careful to position themselves as 'white' historians writing for a 'white'

\footnotetext{
58. While Mudrooroo's Aboriginality is now disputed, he was accepted as an Aboriginal voice at the time.

59. Miller 1985: xvi

60. Fourmile 1989.

61. Huggins 1998: 125.

62. Fesl 1993.
} 
readership and did not presume to put an Indigenous perspective or represent the Indigenous experience. They wanted Australians to know what their society had done to Aboriginal people, and how Aboriginal people had responded to them. ${ }^{63}$ Few historians working in this field would agree with Attwood's position of 1989, 'While sympathetic to the "Aboriginal cause" I have not worked in close contact with Aborigines or been politically involved in any extensive sense ... [I] am dubious of the extent to which our study of the past can be an agent of social and political change. ${ }^{64}$

History is inherently political as we read our contemporary identities into the past. ${ }^{65}$ The emergence of Aboriginal history within Australian history both reflected changing public attitudes within Australian society and influenced those attitudes. The historians of the mid-twentieth century reflected the assimilationist attitudes of their era. Paul Hasluck's career exemplifies how historians can influence political change as he moved from history and journalism into politics where he developed and implemented assimilation policies as the federal Minister for Territories from 1951 to 1963. ${ }^{66}$ The histories of the $1970 \mathrm{~s}$, while still focused on policies, presented them not as colonial policy but as an aspect of Australian history, which Biskup and later Reynolds suggested told Australians about themselves and their society. The changes in historiography reflected changes in attitudes and policies towards Indigenous peoples and other ethnic minorities in Australia. By the mid-1980s and into the 1990s, as historians became more conversant with ethnohistorical research methods and conceptual frameworks, their work investigated Aboriginal society and Aboriginal responses to forced and unforced change. They asked more diverse questions of their historical records and the subjects of study expanded to include Aboriginal involvement in the pastoral industry; the role of Christian missions and Aboriginal responses to Christianity; the complexities of interactions between Aboriginal and nonAboriginal peoples - including the attractions of European foods and tobacco; gender relations within Aboriginal society and between Aboriginal and non-Aboriginal people; and race relations and the politics of race in Australia. ${ }^{67}$ These historians continued to write for a non-Aboriginal readership, but many worked closely with the Aboriginal communities they were researching with the aim that their research would be of interest and assistance to these communities. ${ }^{68}$

During the period in which Aboriginal history emerged there was increasing public disquiet at the social and economic disadvantage experienced by many Aboriginal people. Historians helped to show that this disadvantage was the result of historical factors, rather than social dysfunction. They participated in the debates on

63. Biskup 1973: v; Reynolds 1981; Ryan 1996: 2; McGrath 1987: viii.

64. Attwood 1989: 142.

65. As Attwood's contribution to current debates suggests even he has not been able to remain above the fray (Attwood 2003).

66. Hasluck 1988. See also Geoffrey Partington 1996. The historian Don Watson, who was Prime Minister Paul Keating's speechwriter is credited with influencing policy towards Aboriginal people (Watson 2002).

67. Eg Read 1988; Goodall 1988; Evans et al. 1988; Brock 1993; McGrath 1987; Haebich 1988.

68. Eg three recent books on the Kimberley: Jebb 2002; Choo 2001; Crawford, 2001. My own research in the 1980s was done at the request of Aboriginal communities wanting assistance with community histories eg Brock 1985 and Brock and Kartinyeri 1989. 
how to address this disadvantage by contributing to commissions of inquiry such as the Report of the Royal Commission into Aboriginal Deaths in Custody. ${ }^{69}$ The bringing them home report of the Human Rights and Equal Opportunity Commission followed the early investigations of historian Peter Read and others into the removal of mixed descent children from their families. ${ }^{70}$ The High Court decision which recognised the existence of native title within common law was influenced by historical research both in Australia and elsewhere in the British Commonwealth. ${ }^{71}$ The current attack on Aboriginal history and the historians who work in this field also reflects the changing political climate in Australia. ${ }^{72}$ Aboriginal history has been characterised as 'black armband' history, a phrase coined by the historian Geoffrey Blainey and taken up by Prime Minister Howard. This is not, as a naive reader might suppose, a reference to the many Aboriginal people who died through violence, disease or neglect over the last 200 years, but to a view of the Australian past which is perceived to focus on negative aspects of that history, rather than the laudatory view which was able to turn even military defeats into something positive. ${ }^{73}$

This parallel discussion of Aboriginal and non-Aboriginal historians implies that there are not only different methods used by these historians but that they have such different understandings of the past that the development of a single historiography may not be feasible, let alone desirable. But is there a view which is identifiably Aboriginal, to which all Aboriginal people adhere, with its own "phenomenology, epistemology and ontology' which has continued through 200 years of colonial contact? If one considers Aboriginal life histories as a genre, one finds huge variation in the life experiences described and the way these experiences are expressed. There is a shared experience as subjects of colonisation, a sense of exclusion from mainstream Australian society, and a sense that any achievement is an achievement against the odds, but this does not constitute an Aboriginal ontology. ${ }^{74}$ It is tempting to see a continuation of the binaries of the colonial experience - the 'white' dispossession of Aboriginal lands; the segregation of Aboriginal people from 'white' society; the taking of Aboriginal children by governments and churches - in the production of histories of that past. ${ }^{75}$ But the recent debates about Aboriginal history make clear there is no single non-Aboriginal point of view. Equally there are debates among Aboriginal people about the legacies of the past and their implications for current policies affecting Aboriginal people. ${ }^{76}$ Marcia Langton believes the new generation of non-Indigenous Australians, 'are able to relate to the Aboriginal world in a less troubled way than their parents and they are almost oblivious to Australia's blinding colonial legacy of white supremacy and race hatred' ${ }^{77}$ Even if Langton's optimistic view is realised, the debates about Australian identity, and who constitutes the nation will continue, as will tensions over rights to

69. These historical reports were later published in McGrath 1995.

70. Macintyre and Clark 2003: 153-254.

71. See particularly the judgement of Deane and Gaudron JJ in Bartlett 1993.

72. See Macintyre and Clark 2003 for an excellent discussion of the interaction between historians such as Geoffrey Blainey and Keith Windschuttle and politicians, particularly the Prime

Minister John Howard, especially chapter 7.

73. Blainey 1993: 11; Macintyre and Clark 2003: 128-32.

74. Hodge and Mishra 1990: 102.

75. Thomas (1994: 106) voices disquiet over such simplifications of complex processes, as does Lake 2003. 
land. What is less certain is who will be the participants in these debates. Will Indigenous people continue to be caught in the crossfire, or will they feel empowered to be part of the debate about how our past has informed our present? Will the right to speak be a given, rather than a right for which Indigenous historians must continue to fight? In 1977 James Axtell wrote in his justification of ethnohistory as a legitimate field of scholarship in America that it must not be seen as a 'faddish' response to Vine Deloria's books or radical American Indian politics. In Australia in the early twentyfirst century Indigenous and non-Indigenous historians must ensure that 'Aboriginal history' encompasses radical and conservative Indigenous insights.

\section{References}

Attwood, Bain 1989, The making of the Aborigines, Allen and Unwin, Sydney.

— 1992, 'Introduction', in Power, knowledge and Aborigines, Bain Attwood and John Arnold (eds), special edition of the Journal of Australian Studies 35: i-xvi.

- 1994, 'The paradox of Australian Aboriginal history', Thesis Eleven 38: 118-37.

- 1996, 'Introduction: the past as future - Aborigines, Australia and the (dis)course of history' in Bain Attwood (ed) In the age of Mabo: history, Aborigines and Australia, Allen and Unwin, Sydney: vii-xxxviii.

- 2003, 'Old news from a tabloid historian', The Australian, 6 January.

Austin-Broos, Diane 1994, 'Narratives of the encounter at Ntaria', Oceania 65: 131-50.

Axtell, James 1982, 'Ethnohistory: an historian's viewpoint', in James Axtell (ed) The

European and the Indian: essays in the ethnohistory of colonial North America, Oxford University Press, New York: 3-15.

Bartlett, Richard 1993, The Mabo decision, Butterworths, Sydney.

Barwick, Diane 1971, 'Coranderrk and Cumeroogunga', in T Scarlett Epstein and DH Scarlett (eds), Opportunity and response: pioneers and policy, Hurst, London: 10-68.

Biskup, Peter 1973, Not slaves, not citizens: the Aboriginal problem in Western Australia 1898-1954, University of Queensland Press, St Lucia.

Blainey, Geoffrey 1993, 'Drawing up a balance sheet of our history', Quadrant (July/ August): 11-15.

Briscoe, Gordon 2003, Counting health and identity: a history of Aboriginal health and demography in Western Australia and Queensland, 1900-1940, Aboriginal Studies Press, Canberra.

76. Two of these positions are articulated by Geoff Clark, former Chair of the now disbanded Aboriginal and Torres Strait Commission, who advocates a political agenda with its roots in the 1970s demanding a treaty between Aboriginal and non-Aboriginal Australians and what his critics refer to as 'welfare dependency'. See his address to the 18th Session of the Working Group on Indigenous Populations, Geneva, 27/7/2000 at http://www.atsic.gov.au/issues/ Indigenous_Rights/International/WGIP_18th_session/default.asp; also http:// www.onlineopinion.com.au/2000/Sep00/Clark.htm. Noel Pearson is calling for greater financial autonomy for Aboriginal communities and less reliance on government support ('passive welfare dependency'). See Pearson's web page http:// www.capeyorkpartnerships.com/noelpearson/

Langton 2003: 80 , 
Brock, Peggy 1985, Yura and Udnyu: a history of the Adnyamathanha of the Flinders Ranges, Wakefield Press, Adelaide.

_- 1993, Outback ghettos: a history of Aboriginal institutionalisation and survival, Cambridge University Press, Sydney.

Brock, Peggy and Kartinyeri, Doreen 1989, Poonindie: the rise and destruction of an Aboriginal agricultural community, SA Government Printer, Adelaide.

Broome, Richard 1996, 'Historians, Aborigines and Australia: writing the national past', in Bain Attwood (ed) In the age of Mabo: history, Aborigines and Australia, Allen and Unwin, Sydney: 54-72.

Bropho, Robert 1980, Fringedweller, Alternative Publishing Cooperative, Chippendale.

Choo, Christine 2001, Mission girls: Aboriginal women on catholic missions in the Kimberley 1900-1950, University of Western Australia Press, Nedlands.

Clement, Cathie 2003, 'Mistake Creek', in Robert Manne (ed) Whitewash: on Keith Windschuttle's fabrication of Aboriginal history, Black Inc Agenda, Melbourne: 199-214.

Coleman, Peter 2002, 'The Windschuttle thesis', Quadrant 46(12), December.

Corris, Peter 1969, 'Ethnohistory in Australia', Ethnohistory 16(3): 201-10.

Cowlishaw, Gillian 1992, 'Studying Aborigines: changing canons in anthropology and history' in Bain Attwood and John Arnold (eds) Power, knowledge and Aborigines, Journal of Australian Studies (special edition) 35: 20-31.

Crawford, IM 2001, We won the victory: Aborigines and outsiders on the north-west coast of the Kimberley, Fremantle Arts Press, Fremantle.

Cruikshank, Julie 1990 Life lived like a story University of Nebraska Press, Lincoln.

Deloria, Vine Jr 1969, Custer died for your sins: an Indian manifesto, The Macmillan Company, New York.

Dodson, Michael 1994, 'Voices of the peoples - voices of the earth; indigenous peoples - subjugation or self-determination?', in L van der Vlist (ed) Voices of the earth: indigenous peoples, new partners and the right to self-determination in practice, International Books/NCIP, Amsterdam: 18-29.

Elkin, AP 1944, Citizenship for Aborigines: a national policy, Australasian Publishing Company, Sydney.

_ 1951, 'Reaction and interaction: a food gathering people and European settlement in Australia', American Anthropologist 53: 164-86.

1958, Aborigines and citizenship, Association for the Protection of Native Races, Sydney.

Evans, Raymond, Kay Saunders and Kathryn Cronin 1988, Race relations in colonial Queensland: a history of exclusion, exploitation and extermination, Queensland University Press, St Lucia.

Fesl, Eve Mumewa D 1993, Conned! Queensland University Press, St Lucia.

Fourmile, Henrietta 1989, 'Who owns the past? Aborigines as captives of the archives', Aboriginal History 13: 1-8.

Foxcroft, EJB 1941, Australian native policy: its history especially in Victoria, Melbourne University Press, Melbourne. 
Furniss, Elizabeth 1995, 'Shuswap encounter with Roman Catholic missionaries, 1860-1900', Ethnohistory 42(2): 231-63.

Gilbert, Kevin 1973, Because a white man'll never do it, Angus and Robertson, Sydney.

Ginibi, Ruby Langford 1994, My Bunjalung people, University of Queensland Press, St Lucia.

Goodall, Heather 1988, 'Cryin' out for land rights', in V Burgmann and J Lee (eds) Staining the wattle: a people's history of Australia since 1788, McPhee Gribble/ Penguin, Ringwood: 181-97.

Grieves, Vicki 2003, 'Windschuttle's fabrication of history: a view from the "other" side', Labour History 85: 194-9.

Haebich, Anna 1988, For their own good: Aborigines and government in the southwest of Western Australia 1900-1940, University of Western Australia Press, Nedlands.

Harkin, Michael 1997, Heiltsuks: dialogues of culture and history on the Northwest Coast, University of Nebraska Press, Lincoln.

Hasluck, Paul 1970 [1942], Black Australians: a survey of native policy in Western Australia 1829-97, Melbourne University Press, Melbourne.

— 1988, Shades of darkness: Aboriginal affairs 1925-1965, Melbourne University Press, Melbourne.

Hercus, Luise and Peter Sutton 1986, This is what happened, Australian Institute of Aboriginal Studies, Canberra.

Hodge, Bob and Vijay Mishra 1990, Dark side of the dream: Australian literature and the postcolonial mind, Allen and Unwin, Sydney.

Huggins, Jackie 1998, Sistergirl, Queensland University Press, St Lucia.

Huggins, Rita and Jackie Huggins 1994, Auntie Rita, Aboriginal Studies Press, Canberra.

Jebb, Mary Anne 2002, Blood, sweat and welfare: a history of white bosses and Aboriginal pastoral workers, University of Western Australia Press, Nedlands.

Krech III, Shepard 1991, 'The state of ethnohistory', Annual Review of Anthropology 20: 345-75.

Krupat, A 1985, Those who come after: a study of native American biography, California University Press, Berkley.

Krygier, $\mathrm{M}$ and van Krieken, $\mathrm{R} 2003$, 'The character of the nation' in Manne, Robert (ed) Whitewash: on Keith Windschuttle's fabrication of Aboriginal history, Black Inc Agenda, Melbourne: $81-108$.

Lake, M 2003, 'History and the nation' in Manne, Robert (ed) Whitewash: on Keith Windschuttle's fabrication of Aboriginal History Black Inc Agenda, Melbourne: 160-75

Langford, Ruby 1988, Don't take your love to town, Penguin Books, Ringwood.

Langton, Marcia 2003, 'Whitefella jump up correspondence', Quarterly Essay 12: 77-83.

Lester, Yami 1993, Yami: the autobiography of Yami Lester, Institute for Aboriginal Development, Alice Springs.

Macintyre, Stuart and Anna Clark 2003, The history wars, Melbourne University Press, Carlton, Victoria.

Manne, Robert (ed) 2003, Whitewash: on Keith Windschuttle's fabrication of Aboriginal history, Black Inc Agenda, Melbourne. 
Maynard, John 1997, 'Fred Maynard and the Australian Aboriginal Progressive Association', Aboriginal History 21: 1-13.

- 2002, Aboriginal stars of the turf: jockeys of Australian racing history, Aboriginal Studies Press, Canberra.

_ 2003, 'Australian history: lifting haze or descending fog?', Aboriginal History 27: $139-45$.

McBryde, Isabel 1979, 'Ethnohistory in an Australian context: independent discipline or convenient data quarry?', Aboriginal History 3(2): 128-51.

— 1996, 'Perspectives on the past: an introduction' in Valerie Chapman and Peter Read (eds) Terrible hard biscuits: a reader in Aboriginal history, Allen and Unwin, Sydney: 1-15.

McConville, Patrick 1985, 'The role of Aboriginal languages in story: a comment on Shaw', Australian Aboriginal Studies 2: 74-6.

McGrath, Ann 1987, Born in the cattle: Aborigines in the cattle country, Allen and Unwin, Sydney.

1995 (ed), Contested ground: Australian Aborigines under the British Crown, Allen and Unwin, Sydney.

Miller, James 1985, Koorie: a will to win: the heroic resistance, survival and triumph of black Australia, Angus and Robertson, Sydney.

Miliroy, J, J Host and T Stannage (eds) 2001, Wordal, Centre for Western Australian History, University of Western Australia, Nedlands.

Morgan, Sally 1989, Wanamurraganya: the story of Jack McPhee, Fremantle Arts Press, Fremantle.

Moses, Dirk 2003, 'Rendering the past less unpalatable', The Australian 13 January.

Muecke, S, A Rumsey and B Wirrunmurra 1985, 'Pigeon the outlaw: history as texts', Aboriginal History 9: 81-100.

Munro, Morndi 1996, Emerarra: a man of Merarra, Mary Anne Jebb (ed), Magabala Books, Broome.

Murray, David 1991, Forked tongues: speech, writing and representation in North American Indian texts, Indiana University Press, Bloomington.

Nannup, Alice 1992, When the pelican laughed, Fremantle Arts Press, Fremantle.

Ngabidj, Grant 1981, My country of the pelican dreaming: the life of an Australian Aborigine of the Gadjerong, Grant Ngabidj 1904-1977, as told to Bruce Shaw, Australian Institute of Aboriginal Studies, Canberra.

Partington, Geoffrey 1996, Hasluck versus Coombs: white politics and Australia's Aborigines, Quakers Hill Press, Sydney.

Patrick, Peggy 2003, 'Statement of Peggy Patrick' in Robert Manne (ed) Whitewash: on Keith Windschuttle's fabrication of Aboriginal history, Black Inc Agenda, Melbourne: 215-17.

Pearson, Noel, http://www.capeyorkpartnerships.com/noelpearson.

Perkins, Charles 1975, A bastard like me, Ure Smith, Sydney.

Pilkington, Doris (Nugi Garimara) 1996, Follow the rabbit-proof fence, University of Queensland Press, St Lucia. 
Price, A Grenfell 1949, White settlers and native peoples: an historical study of racial contacts between English-speaking whites and Aboriginal peoples in the United States, Canada, Australia and New Zealand, Georgian House, Melbourne, 1949.

Read, Peter 1988, The hundred years war: the Wiradjuri and the State, ANU Press, Canberra.

Read, Peter and Japaljarri, Engineer Jack 1978, "The price of tobacco: the journey of the Warlmala to Wave Hill 1928', Aboriginal History 2(1): 141-8.

Reynolds, Henry 1981, The other side of the frontier: Aboriginal resistance to the European invasion of Australia, Penguin Books, Ringwood.

-2002, 'Historians at war', The Weekend Australian 14-15 December: 11.

Roe, Paddy and Muecke, Stephen 1993, Gularabulu: stories from the west Kimberley, Fremantle Arts Press, Fremantle.

Rose, Deborah Bird 1991, Hidden histories, Aboriginal Studies Press, Canberra.

Rosser, Bill 1985, Dreamtime nightmares: biographies of Aborigines under the Queensland Aborigines Act, Australian Institute of Aboriginal Studies, Canberra.

— 1990, Up rode the troopers: the Black police in Queensland, Queensland University Press, St Lucia.

Roughsey, Elsie (Labumore) 1984; An Aboriginal mother tells of the old and the new, McPhee Gribble, Fitzroy.

Rowley, CD 1970a, The destruction of Aboriginal society, ANU Press, Canberra.

— 1970b, Outcasts in white Australia, ANU Press, Canberra.

- 1971, The remote Aborigines, ANU Press, Canberra.

Rubuntja, Wenton with Jenny Green 2002, The town grew up dancing, Jukurrpa Books, Alice Springs.

Ryan, Lyndall 1996 [1981], The Aboriginal Tasmanians, University of Queensland Press, St Lucia.

- 2002, 'No historian enjoys a monopoly of truth', The Australian 17 December.

-2003, 'Who is the fabricator?' in Robert Manne (ed) Whitewash: on Keith Windschuttle's fabrication of Aboriginal history, Black Inc Agenda, Melbourne.

Sandall, Roger 2002, 'Mr Windschuttle versus the professors', The Australian 23 December: 11.

Shaw, Bruce 1983, Banggaiyerri: the story of Jack Sullivan, Australian Institute of Aboriginal Studies, Canberra.

1984 'How Aboriginal life histories can be written: a response to the review "Language and dignity", Australian Aboriginal Studies 1: 47-52.

1985 'A reply to McConville' Australian Aboriginal Studies 2: 76-8.

Sheridan, Thomas E 1988, 'How to tell the story of a "People without history": narrative versus ethnohistorical approaches to the study of the Yacqui Indians through time', Journal of the South West 30: 168-89.

Spicer, Edward H 1969, 'Types of contact and processes of change', in EH Spicer (ed) Perspectives in American Indian cultural change, University of Chicago Press, Chicago. 
Thomas, Nicholas 1994, Colonialism's culture: anthropology, travel and government Polity Press, Cambridge.

Trigger, Bruce 1982, 'Ethnohistory: problems and perspectives' Ethnohistory 29(1): 1-19.

— 1985, Natives and newcomers: Canada's heroic age reconsidered, McGill-Queens University Press, Kingston.

Trigger, David 1987, Whitefella comin': Aboriginal responses to colonialism in northern Australia, Cambridge University Press, Melbourne.

Tucker, Margaret 1977, If everyone cared: autobiography of Margaret Tucker, Ure Smith, Sydney.

Ward, Glenyse 1995, Wandering girl, Magabala Books, Broome.

Watson, Don 2002, Recollections of a bleeding heart: a portrait of Paul Keating PM, Knopf, Sydney.

Wharton, Herb 1994, Cattle camp: Murrie drovers and their stories, Queensland University Press, St Lucia.

Willis, HA 2002, 'Rewriting history', The West Australian 28 December: 16.

Windschuttle, Keith 1994, The killing of history: how a discipline is being murdered by literary critics and social theorists, Macleay, Paddington.

- 2002a, The fabrication of Aboriginal history, Volume one Van Diemen's Land 1804-1847, Macleay Press, Sydney.

- 2002b, 'The historian as prophet and redeemer', Quadrant 46(12): 9-18.

Wolf, Eric 1982, Europe and the people without history, University of California Press, Berkeley.

Wolfe, Patrick 1994, 'Nation and miscegenation: discursive continuity in the post-Mabo era', Social Analysis 36: 93-152. 